\title{
S NOTE ON Citations AND COINAGE
}

In citing the Alfonsine Codes the initial number refers to the book, the second to the title, and the third to the law or laws. For example, E 4, 2, 7-9 means Espéculo, bk. 4, tit. 2, laws 7-9. For other legal compilations not divided into books and titles the numbers refer to specific laws. In citing the Cortes I refer to the place, year, and article, for example, Seville 1252, art. 1. Among the various editions, I cite Georg Gross for Seville 1252, Antonio López Ferreiro for Seville 1253, Manuel González Jiménez for Seville 1261, and Cortes de los antiguos reinos de Castilla y León for Valladolid 1258 and Jerez 1268.

All translations of biblical passages are from The Saint Joseph Edition of the New American Bible with Revised New Testament and Psalms (New York: Catholic Book Publishing Co., 1992).

In chapter 12 I discuss Alfonso X's various permutations of the coinage, but it will help the reader to know that ordinarily prices were calculated in terms of the maravedi (lat. morabetinus), the sueldo (lat. solidus), and the dinero (lat. denarius). Both a gold coin and a money of account, the maravedi theoretically consisted of 15 sueldos or 180 dineros. 



$$
\begin{array}{r}
\boldsymbol{S} \text { ALFONSO X, } \\
\text { THE JUSTINIAN OF HIS AGE }
\end{array}
$$


